\title{
Implementing Innovations in International Law
}

\author{
Book Review \\ Cassese, Antonio (ed), Realizing Utopia: The Future of International Law (Oxford \\ University Press, 2012). 728 pages; $£ 95$ (hardback).
}

Matthew Hoisington ${ }^{*}$

Taking innovations to market is difficult in any discipline-perhaps most especially this of ours. Despite their omnipresence in scholarly journals and other forms of published work, public international law does not lend itself naturally to the implementation of radical projects. Formally speaking, the system, which exists largely to pacify the divergent interests of sovereign equals while trying to stitch them together in a universally applicable order, advertises stability as its competitive advantage. Each new instrument adopted represents the standard against which subsequent actions will be judged-a notch where later ideas are braced. Settled, stable expectations are the goal. Amendments are infrequent and require substantial effort. Each new customary rule applies until it is replaced or superseded. Change is slow and incremental. Judgments of international tribunals bind the parties and, despite the formal absence of stare decisis, will often be used as powerful argumentative devices in other contexts. When the rules are clear and well-entrenched, the system is widely considered to be effective. True innovation springs to life and gains acceptance only in the aftermath of crisis. It was long ago that positivism, that paradigm of clarity and objectivitynotwithstanding its uneasy relationship with reality-replaced the messier tenets of naturalism as the predominant form of international legal practice.

While this characterisation of present-day public international law may be true-and most in the mainstream would accept the general characterisation, if not the implication-it nonetheless fosters considerable frustration among pioneering international jurists. Those seeking to innovate through new ideas encounter major, and sometimes insurmountable, obstacles within a system that

Associate Legal Officer, United Nations, Office of Legal Affairs. This review is written in my personal capacity and does not necessarily reflect the views of the United Nations.

Copyright $\odot$ the Author(s).

This work is licensed under a Creative Commons Attribution-NonCommercial-NoDerivs 3.0 License. 
prefers the incessant recitation of the status quo. In order to be taken seriously in their creative pursuits, they must tread lightly, careful not to unduly disturb the formal stability of the order that they inherit. To do otherwise is to risk professional ostracism or, even worse, to be ignored altogether.

The late (and great) Antonio Cassese's edited volume represents an excellent example of the restlessness that accompanies such dissonance. Wedged between the inescapable constraints of the real world and the untapped, unrealised possibilities of radical ideas, it tries to create for itself a defensible middle-position. In a telling introductory chapter, Cassese recalls the words from Aldous Huxley's Proper Studies, where Huxley, writing in the early part of the twentieth century, drew a distinction between different categories of sociologists. First, there were the 'Technicians' who are inclined 'to accept all too complacently the main framework of the structure whose details they are trying to improve' and '[accept] things as they are, but too uncritically; for along with the existing social institutions, they accept the conception of human nature which the institutions imply.1 A second category is made up of 'Utopians' who 'are too preoccupied with what ought to be to pay any serious attention to what is. Outward reality disgusts them; the contemporary dream is the universe in which they live. The subject of their meditations is not man, but a monster of rationality and virtue ....2 In between these two extremes lay the 'judicious reformer' who 'wants to know what direction reform should take and what are its limits' ${ }^{3}$ and to which the Technician and the Utopian 'have little or nothing to say."

It is with the 'judicious reformer' that Cassese attempts to draw a connection to his project. In his view what is needed in the field of international law, and the charge he has given to his contributors to find, is a proper balance of 'imaginative power' and 'clarity. 5 The 'judicious reformer' of international law knows how to use 'the traditional tools of jurisprudence' and is also 'alert to the present-to its merits but also to its pitfalls-and suggests realistic and viable avenues in order to avoid, at least to some extent, those pitfalls encountered when trying to build a better path. ${ }^{6}$ This latter characteristic of awareness might be the prevailing element of Cassese's projection of Huxley's 'judicious reformer'

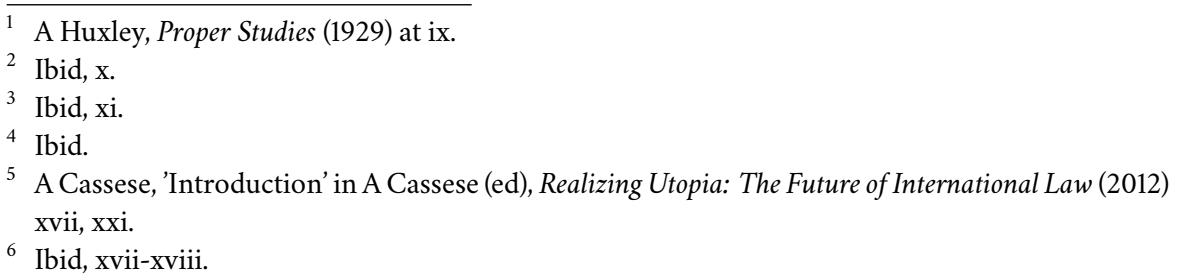


onto the work of the international jurist. Awareness of the ways the system works and does not work; awareness of the cracks and crevices that can be exploited or filled (as well as those that must be left alone); awareness of the futility of idealism in the face of power; awareness of the stubborn steadfastness of constitutional orders; awareness of the responsibilities of governance; awareness of the self-perpetuating motives of international institutions; awareness, perhaps most of all, of the subservient role that the international jurist is forced to play to other professional headliners in the making of international life.

Cassese's method for the volume, and the way in which he introduces the work of the other contributors, raises a number of questions about the place of the discipline and the jurist in the international system. It is a book of substance, but it tells us more about the style to which the authors are willing to adhere than it does about any one set of programmatic prescriptions. Instead of lone voices calling out into the wilderness (or, as Cassese terms it, 'wild speculation') ${ }^{7}$ what we have is an attempt to speak in sober, modest, gently progressive terms. The justification of this is '... to avoid the extremes of both blind acquiescence to present conditions and the illusion of being able to revolutionize the fundamentals. ${ }^{8}$ In framing the challenge before him, the editor also accepts the two 'apparently irreconcilable assumptions of law' articulated by Sir Robert Jennings. ' We are, Cassese recalls, stuck in Jennings' dilemma of certainty and change. Both are needed but neither is perfectly attainable. Antiquated laws that lose touch with reality risk devolving into an 'empty corpus', while at the same time the 'machinery' for the reform of public international law neither exists nor is likely to emerge in the near future. ${ }^{10}$ The best way to unshackle international law is to engage in the hard work of incremental progress. We must, he writes, '... look not at the stars, but closer to home, to the planets that turn around the earth ... [and] charg[e] our intellectual weapons with relatively short-range ammunition.'11

Despite this nod to the necessity of judicious, self-aware, and realistic conduct-not to mention geocentric astronomy-we nonetheless find assembled in Cassese's collection contributions from some of the discipline's most celebrated outliers. There is Martti Koskenniemi in his familiar role as 'crit', searching in earnest for an elusive 'oceanic feeling' (chapter 1). Nehal Bhuta, as well, does an admirable turn in analysing epochal shifts, particularly as they might

\footnotetext{
Ibid, xxi.

8 Ibid, xvii.

9 Ibid, xviii.

${ }^{10}$ Ibid.

${ }^{11}$ Ibid, xxii.
} 
relate to international legal personality (chapter 6). Additional interventions of note include José Alvarez's assertion of the enduring indispensability of State Sovereignty (chapter 3), Philip Alston's lamentations on the prospects of United Nations reform (chapter 4), Bardo Fassbender's sober appraisal of the UN Security Council's progressive potential (chapter 5), W. Michael Riesman's prospectus on the future of investment law and arbitration (chapter 22), and Judge Abdulqawi Yusuf's discursus on the evolving right to economic, social and cultural self-determination (chapter 30). Included as well are subject matter essays (chapters $28-43$ ) by a vast array of prominent and well-respected international jurists on issues as diverse as trade, the environment, the jus ad bellum, terrorism, the jus in bello, genetic manipulation, and cyberspace. This is, to say the least, an impressive bunch.

Lording over them all is the editor himself. The author or co-author of no less than seven thematic chapters on a broad range of topics, including modern sovereignty, jus cogens, the International Court of Justice, the domestic implementation of international rules, institutional fact-finding, and internal armed conflict, the multitalented Cassese-distinguished first president of both the International Criminal Tribunal for the former Yugoslavia and the Special Tribunal for Lebanon-undertakes a tremendous effort to push his reformist agenda across the spectrum of public international law. Those familiar with his academic and professional achievements, which are innumerable and proverbial, will recognise the enthusiasm, verge, literacy, humour, stubbornness and intelligence that made him a central participant in some of the late twentieth and early twenty-first century's most famous international legal epochs. They might also recognise in his writings certain signatures, such as the commitment to see the law through the lens of humanity, the hope that customary law will evolve to meet the challenges and gaps in the existing order, and the ability to confront complex legal questions in a fair, straightforward and accessible manner.

In light of the prodigious talents of Cassese and his contributors, what does it say about the discipline of international law when some of our most brilliant, original thinkers feel duty-bound to subject themselves to the role of judicious reformer[s]'? While prudence has its virtues, certainly such deference is not the rule in other disciplines, where creativity enjoys a more prominent role. The drivers of development and innovation at technology corporations, for instance, do not voluntarily subject themselves to restrictions on their ideas. Rather, they do everything within their power to foster such activities. Google famously maintains a secret lab, with the moniker Google X, where speculative, futuristic projects such as space elevators and a 'web of things', are currently being imagined 
and tested. ${ }^{12}$ The Google X model follows-on from the precedent of Xerox Palo Alto Research Center (PARC)-whose charter was to 'create the office of the future ${ }^{13}$-where the personal computer was invented, and Lockheed Martin's Advance Development Programs (better known by its other name-Skunk Works), where the first US jet was conceived and built in 143 days. ${ }^{14}$ Governments have also welcomed the use of innovative institutional models. The US Defense Advanced Research Projects Agency (DARPA), the primary innovative arm of the US Department of Defense, which seeks revolutionary advantages for the US military, is responsible for the creation of the Internet and the technology behind global positioning systems (GPS). ${ }^{15}$ The list goes on. ${ }^{16}$ Are international jurists not capable of adopting similar approaches? Can they not be the creative engineers and 'skunk workers' of the international system?

Comparing international law and international jurists to professionals in the technology, aeronautics or defense industries may strike many as unfair or fanciful, but a great deal can be learned from the way professionals in other disciplines are able to foster their innovative ideas and take them to market. In Cassese's volume, the issue of implementation is addressed in the usual methods, mainly through the interplay between international and domestic law (chapters 15-16), judicial review (chapters 19-23), and fact-finding induced pressure (chapters 24-27). According to this view, international law exists on one level, dominated largely by states, and it must be brought into effect by its adoption, internalisation and use domestically. This corresponds to the introduction of products into the market and their subsequent adoption or

${ }^{12}$ C C Miller and N Bilton, 'Google's Lab of Wildest Dreams', The New York Times, 13 November 2011 <http://www.nytimes.com/2011/11/14/technology/at-google-x-a-top-secretlab-dreaming-up-the-future.html?pagewanted=all\&_r=0> [accessed 5 May 2013].

${ }^{13}$ See 'Parc Today', Parc. A Xerox Company, <http://www.parc.com/about/> [accessed 3 April 2013].

${ }^{14}$ See 'Skunk Works ${ }^{\circledR}$ ', Lockheed Martin, <http://www.lockheedmartin.com/us/aeronaut ics/skunkworks.html> [accessed 3 April 2013].

${ }^{15}$ See generally DARPA, Fifty Years of Bridging the Gap (2008) at 54-55 and 78-85, <http://www.darpa.mil/about/history/first_50_years.aspx> [accessed 3 April 2013].

16 The DARPA model was recently applied to the U.S. Department of Energy in the form of the Advanced Research Projects Agency - Energy (ARPA-E), which focuses on, among other things, '... creative "out-of-the-box" transformational energy research'. See Advanced Research Projects Agency-Energy, <http://arpa-e.energy.gov/?q=arpa-e-site-page/about> [accessed 3 April 2013]. The United States Central Intelligence Agency also implores its analysts to pursue innovative thinking through its 'CIA Red Cell', which 'has been charged by the Director of Intelligence with taking a pronounced "out-of-the-box" approach that will provoke thought and offer an alternative viewpoint on the full range of analytic issues'. See Central Intelligence Agency, <https://www.cia.gov/offices-of-cia/intelligence-analysis/history.html> [accessed 3 April 2013]. 
purchase by market participants. The problem with the implementation of new ideas in international law is that they are stunted at the first level and sclerotic at the second. Because of existing processes that limit international lawmaking, new rules rarely get the chance to be tested domestically, even where they are needed. In sum, international law suffers from a dearth of vigorous, bold and imaginative research and development. To make matters worse, there are few, if any, institutional arrangements that allow for the introduction and beta-testing of new and innovative ideas.

The limits of the analogy are also worth noting. The incentives are certainly different. For one, international law is not per se interested in production. Whether more law is better, or whether the old law must be replaced by something new and innovative depends to a very large extent on the situation. Moreover, it should go without saying that international law's objectives are very different than, for instance, the technology or defense industry's. The preamble to the Charter of the United Nations states the determination, among other things, 'to save succeeding generations from the scourge of war.'17 Meanwhile, Google's 2012 mission statement is 'to organize the world's information and make it universally accessible and useful', ${ }^{18}$ while DARPA's avowed purpose is '...to maintain the technological superiority of the US military and prevent technological surprise from harming our national security by sponsoring revolutionary, high-payoff research bridging the gap between fundamental discoveries and their military use. ${ }^{\prime}{ }^{19}$ There is an element of humanity and responsibility inherent in the practice of international law that is not necessarily reflected in enterprises, such as Google or DARPA, where innovation has enjoyed more widespread success. (Even national defense, with its avowed high-minded purposes, often involves the breaking-down, rather than the building-up of humanity.) Finally, new ideas must be 'tested' quite differently in the international legal context than in other areas. Because international law cuts so close to the vital interests and lives of its subjects, those seeking to innovate must carefully avoid unintended consequences.

Despite these clear differences, commonalities, such as the need to constantly challenge what already exists and the necessity of innovation-friendly institutional arrangements do apply, and international jurists, as the rightful engineers of the international order, can and must do a better job of creating conditions

\footnotetext{
${ }^{17}$ Charter of the United Nations and Statute of the International Court of Justice, Preamble.

${ }^{18}$ See 'Company', Google, <http://www.google.com/about/company/> [accessed 3 April 2013].

${ }^{19}$ See Defense Advanced Research Projects Agency, <http://www.darpa.mil/about.aspx> [accessed 3 April 2013].
} 
conducive to innovative change. This, in turn, will give life to their transformative intellectual projects.

The first part of the solution, which is something Cassese and his contributors unfortunately do not address, is that the international jurist need not fall neatly into one category or another. Rather, in his or her work, he or she may vacillate between different roles. The academic who enters public service knows this well, but the full-time practitioner could use some lessons. The key, paradoxically, is to retain the same sort of hyper self-awareness that led Cassese to call his contributors to the 'judicious reformers' camp in the first place. The effort it takes to innovate and experiment can take place alongside the performance of more mundane professional tasks. The expert and experienced international jurist will know full well when he or she is in the mode of innovator/utopian as opposed to technician, 'judicious reformer' and so on.

A second part of the solution, which is also not addressed sufficiently in Realizing Utopia, is to institutionalise systems that not only create outlets for innovative projects but also offer ready-set processes for their implementation. This kind of effort is not easy. It requires a shift in focus from end results to processes. It is largely true, as Cassese writes, that '... international law lacks an efficient international mechanism for the abolition of outdated legal rules and the formation of more modern and adequate prescriptions. ${ }^{20}$ Even where such processes exist in a formal sense, they ultimately require the added elements of favourable informal practices and bold personalities in order for ideas to be carried into execution. Building up these informal practices and identifying the right people to carry out the tasks involved takes experience, leadership and persistent effort. Subsequent dilemmas arise. When good processes fail, what happens? Think of the International Law Commission or, better yet, the Ad hoc Committee established pursuant to United Nations General Assembly resolution 51/210 of 17 December 1996. Fuelled by strong institutional linkages and mandates, both bodies have contributed to major successes in public international law-the Vienna Convention on the Law of Treaties and the Rome Statute of the International Criminal Court, for the former, or, for the latter, a number of sectoral conventions on international terrorism-but they have also encountered challenges-such as the Draft Articles on the Responsibility of International Organizations for Internationally Wrongful Acts for the former, and the Draft Comprehensive Convention on International Terrorism for the latter-which have proven difficult to overcome. In such cases, additional elements beyond

${ }^{20}$ Cassese, above n 5 , xviii 
the existing processes, including better means for handling disputes or breaking deadlock, and not mere reforms, are required.

Finally, it should be recalled that while reform is always an option, it should not exclude alternative possibilities. If the current processes that exist do not work, then in some circumstances they need to be cast aside and reinvented completely. To accept the limitations of existing processes as given, and internalise and entrench the distance between the present and the perfect, is to self-impose a restriction. Plenty of difficulties and challenges exist in the discipline without their reification by international jurists. Little is gained by walking to the base of a wall and staring up in learned recognition of its sheer fortitude. Contrary to the general approach adopted in Realizing Utopia, some barriers need to be smashed to bits rather than deconstructed brick-by-brick.

Whatever the method for its creation, application-and destruction-the ultimate test of international law will remain its effectiveness. But in order to determine what is effective, the international jurist must be able to empirically test new ideas and hypotheses. Perhaps the most pressing problem with the current international order is that it suppresses such activities out of a near-theological allegiance to stability. Laws are etched in stone rather than written in ways that allows for their continuous renewal and reinvention. To recall Sir Robert Jennings' 'irreconcilable assumptions' once again, in the current order certainty almost always trumps change, and change has no natural pathway to implementation. This creates a self-defeating paradigm. How will we ever know whether a new law or system of rules might function better than the current order if it never gets the chance to operate? The devotion to stability only makes sense if it is assumed that the incorporation of divergent projects creates trade-offs, whereby the benefits of stability are sacrificed to create space for new ideas. This assumption is categorically false. Innovative pursuits can easily take place alongside the routine, baseline functions of organisations. Moreover, such efforts need not detract from existing resources. The industries and disciplines mentioned previously have all found ways to execute on new ideas without sacrificing core competencies.

In the final analysis, Cassese's final book is about realising Utopia, not imagining it. And to this noble goal, he and his cadre of able jurists have aptly applied their considerable talents. The idea of a realistic Utopia is, Cassese admits, an oxymoron; however, as he writes in the volume's conclusion:

We have offered in this book a vast panoply of suggestions aimed at promoting reform and progress of the international society over 
the next two to three decades ... it is now for diplomats, politicians, national and international lawmakers, but also for NGOs and national and international public opinion to decide ... whether they are worth being implemented on the ground, or are nothing more than stillborn dreams. ${ }^{21}$

Cassese's final message is a challenge. The position taken here is to welcome it. It is now up to us. In order to avoid the fate of 'stillborn dreams' we must take concerted and focused action. In carrying out this charge, however, it might not hurt to lean a little more toward Utopia and a little less toward the realistic than Cassese suggests.

${ }^{21}$ A Casese, 'Gathering Up the Main Threads' in A Cassese (ed), Realizing Utopia: The Future of International Law (2012) 645, 683-84. 